ISSN: 0213-3563

https://doi.org/10.14201/azafea202123353373

\title{
A MANIFESTAÇÃO CONFLITIVA DA DÍKE NO INQUÉRITO DE ÉDIPO
}

\section{The Conflictive Manifestation of the Dike in Oedipous' Survey}

Ricardo Manoel De Oliveira Morais

Universidade Federal de Minas Gerais (Brasil)

Recibido: 14 de diciembre de 2020

Aceptado: 16 de noviembre de 2021

\section{RESUMO}

O objetivo é analisar a tensão entre duas formas díke na tragédia de Sófocles Édipo rei. Como as tragédias ocupavam um papel privilegiado na pólis, as encenações constituíam uma instituição política. Devido a isso, as tragédias representavam certos conflitos sociais e políticos entre uma tradição arcaica e uma nova ordem democrática, tensões estas que podem ser evidenciadas na investigação promovida por Édipo. Neste inquérito há um conflito entre duas formas de justiça, uma divina (tradicional) e outra humana (democrática e institucional). $\mathrm{O}$ artigo, primeiramente, descreve a relação entre tragédia e pólis; em seguida, assinala o conflito que se desenhava na pólis democrática e que se refletia, de certo modo, nas peças trágicas; por fim, examina, em Édipo $r e i$, a articulação antagônica entre a díke tradicional e a humana.

Palavras-chave: pólis; tragédia; conflito; díke; Sófocles.

\section{ABSTRACT}

The aim is to analyze the tension between two forms dike in Sophocles' Oedipus the king. Since the tragedies occupied a privileged role in the pólis, the tragic presentations constituted a political institution. So, the pieces reproduced some social and political conflicts between an archaic tradition and a new democratic order. Such tension may be evidenced in the investigation promoted by Oedipus. In his inquiry there is a conflict between the two forms of justice, one divine (traditional) and the other human (democratic and ins- 
titutional). This text, firstly, describes the relationship between tragedy and pólis; afterwards, it points the conflict that was expressed in democratic pólis and reflected in the tragedies; finally, it examines, in Oedipus The king, the antagonistic articulation between the traditional and the human dike.

Key words: pólis; tragedy; conflict; dike; Sophocles.

\section{INTRODUÇÃO}

Este artigo tem por objetivo analisar uma tensão entre dois tipos de díke que se faz presente na tragédia grega. Conforme será examinado, esta tensão entre as duas formas de justiça que se manifesta nas peças trágicas é reflexo de um conflito maior que precedeu a emergência da democracia ateniense e que toma corpo e marca a pólis democrática: o antagonismo entre a tradição (oligárquica) e o novo. Uma vez que esta tensão se manifesta abertamente na peça Édipo rei de Sófocles, o último momento do texto será dedicado a um exame mais detido desta peça ${ }^{1}$, no qual as reflexões de Foucault e as de Vernant e Vidal-Naquet serão centrais.

As tragédias, diferentemente do que pode parecer, possuem forte relação com a pólis e, por conseguinte, com o pensamento e com a realidade política clássica, relação esta que vem sendo resgatada por estudiosos. Goldhill (2008) aponta três correntes interpretativas sobre o papel da tragédia no pensamento político, uma que tenta encontrar uma mensagem política específica na peça como se a tragédia tratasse de questões políticas particulares do presente, ainda que o relato trágico fosse situado no passado e em contextos

1. Importante ressaltar que o conflito que marcou o processo de consolidação da democracia grega pode ser constatado em diversos textos trágicos. Mais ainda, a própria tensão entre as duas formas de dike - a divina-tradicional e a humana-democrática - pode também ser verificada em outras peças, como Antígona (também de Sófocles). Todavia, a escolha por Édipo rei se fundamenta em duas razões. A primeira, da ordem do pragmático e do executável, decorre da impossibilidade de, em um artigo, analisar diversas peças trágicas sem incorrer na superficialidade. A segunda deriva do fato de que na referida peça sofocliana se pode verificar a concentração, em uma mesma figura (e não em um diálogo ou no todo da peça), que é a de Édipo, uma série de tensões que marcavam a relação entre pólis e tragédia como: a tensão de um monarca (sujeito que concentrava todo o poder político em si) preocupado em realizar uma justiça referenciada na pólis; o conflito pessoal vivido por aquele que buscava purgar a cidade de uma peste de origem aparentemente divina por instrumentos humanos; o antagonismo entre o racionalismo político humano e a contingência divina. 
distantes do ateniense; uma segunda corrente, que percebe a tragédia como uma compreensão do político em si, tendo a função de recontar os mitos do passado na pólis democrática, sendo a tragédia o sintoma de um choque entre dois sistemas, problematizando, com isso, a tensão entre responsabilidade política, poder, controle, violência e autoridade; e uma terceira corrente que analisa a tragédia como uma linguagem político-teatral onde estão presentes expressões de transgressão da ordem. Logo, a tragédia não seria uma mera reapresentação dos mitos, mas a inscrição da tradição na nova ordem democrática.

Assim, será evidenciado, num primeiro momento, a partir dessa relação entre tragédia e política, que as apresentações trágicas ocupavam um papel privilegiado na pólis, tanto no que diz respeito aos temas apresentados quanto no que tange às próprias apresentações. Com isso, pode-se dizer que as tragédias eram uma espécie de instituição política. Em seguida, será apontado que, apesar de estarem fortemente relacionadas à democracia ateniense, as peças refletiam um conflito entre a tradição e o novo, entre valores em crise e a nova ordem que tenta se consolidar. Tal conflito será examinado na investigação de Édipo pelo inquérito, onde é possível constatar, ao mesmo tempo, a tensão e a articulação entre duas formas de justiça, uma divina e outra humana.

\section{Pólis e a tragédia grega}

As tragédias, diferentemente do que pode parecer de início, possuem uma forte relação com a pólis grega. Vidal-Naquet e Vernant (1988), por exemplo, notam que os discursos das tragédias se assemelham aos pronunciados nas cortes e reuniões políticas. A linguagem utilizada pelos trágicos tinha a mesma estrutura que a empregada nas instituições políticas. Ober e Strauss $(1991,243)$ assinalam a íntima relação entre o escopo das tragédias e o dos discursos políticos, ambos servindo como mediadores para apresentação e resolução política de conflitos sociais, conflitos estes refletidos nas peças. Leo Strauss (1988), por sua vez, sobre a questão política, aponta que toda teoria que indaga por questões fundamentais (ética, direito, virtude, melhor regime), seja ela ética, jurídica ou econômica, ela será, essencialmente, política. Deve-se ressaltar também o fato de que a organização dos festivais trágicos ficava a cargo das instituições políticas. Tanto a escolha do indivíduo que 
iria financiar os espetáculos quanto os concursos entre os autores trágicos eram tidos como assuntos referentes à pólis.

Goldhill (2008, 63-64) chama a atenção para o fato de que a organização espacial do auditório onde eram encenadas as tragédias refletia a disposição política da democracia ateniense. Nos festivais, que reuniam até 16 mil pessoas, a maior parte era de atenienses e a geografia do auditório retratava um mapa político. Havia lugares especiais reservados aos membros do conselho, aos diplomatas estrangeiros, sacerdotes e dignitários do Estado, assim como assentos destinados aos efebos. Os demais espaços destinavam-se a estrangeiros e interessados em presenciar as encenações. Além disso, as cerimônias que abriam a Grande Dionísia, realizadas em frente aos cidadãos antes exibições, expressavam claramente ideais cívicos ${ }^{2}$. As tragédias, neste sentido, eram uma instituição da democracia, da pólis.

Segundo Tierno $(2014,5)$, a etimologia de pólis é vaga e remete a cidadela elevada (akró-polis: cidade alta), cujo cume fortificado os gregos da "era obscura" utilizavam para defesa. Para Bobbio (1998, 949-950), "por pólis se entende uma cidade autônoma e soberana, cujo quadro institucional é caracterizado por uma ou várias magistraturas, por um conselho e por uma assembleia de cidadãos (politai)". Evidente que (e Bobbio faz tal ressalva) uma conceituação de pólis é fruto de abstrações de situações históricas diversas entre si, já que pólis se refere "quer aos regimes oligárquicos (típicos dos séculos VIII-VI, mas verificáveis também nos séculos posteriores), quer aos regimes democráticos que se encontram a partir mais ou menos do século VI" (idem).

Entretanto, antes de a pólis democrática emergir, as instituições gregas passaram por um processo de abertura. A emergência do que se entende por pólis foi fruto de um lento processo político que parece ter tido como marco inicial a comunidade aristocrática. Oliveira (2013, 30-31) explica que "a formação do sistema da pólis modificará inteiramente, desestruturando o regime

2. Na primeira, dez generais (principais figuras militares e políticas) derramaram uma libação para o sacrifício de abertura. Raramente, no calendário, tais oficiais eleitos desempenhavam um papel teatral. Tal ritual enfatizava o poder da pólis e a importância política da ocasião. $\mathrm{Na}$ segunda, anunciava-se os nomes dos cidadãos que beneficiaram o estado, recebendo uma coroa por seus serviços, o que ratificava o princípio do dever de servir o estado e a obrigação para com a comunidade. Em terceiro, era feita uma procissão que exibia a prata paga pelas poleis ao império ateniense, o que glorificava Atenas militar e politicamente. Isso era feito na frente dos embaixadores estrangeiros. Por fim, havia um desfile dos efebos cujos pais foram mortos lutando pelo estado (Goldhill, 2008, 63). 
gentílico arcaico e o despotismo das monarquias patriarcais a ele intimamente vinculado". O referido processo tem como marco inicial "a expansão e gradual agregação das comunidades naturais baseadas no parentesco familiar, alcança a conformar uma associação política compreensiva socialmente diferenciada e complexa" (Tierno, 2015, 5). Tal fenômeno é bastante complexo e amplo e, não havendo como mapeá-lo num artigo, vale apontar alguns dos acontecimentos situados entre os séculos VIII e VI a. C.

Grosso modo, o processo histórico de constituição da pólis é atrelado à abrupta urbanização ocorrida no mundo grego antigo "entre os séculos VIII e VII, urbanização para a qual contribuíram vários fatores, tais como a intensificação do processo tecnológico e artesanal, a passagem de uma economia natural (escambo) a uma economia monetária e em grande surto de atividades comerciais" (Oliveira, 2013, 31). Tal fenômeno viabilizou a formação de uma comunidade que se projetava para além de uma estrutura agrária, levando a uma inevitável pulverização da autoridade monolítica do basileus. Com a dissolução gradual do mundo hierárquico da soberania arcaica, operou-se uma reestruturação da ordem comunitária que culminou na descentralização e coletivização do poder. Ainda que "O aparecimento da polis [constitua], na história do pensamento grego, um acontecimento decisivo” (Vernant, 2002, 53), é necessário notar que a referida descentralização e coletivização do poder não foi um processo linear, mas, como o é todo deslocamento de poder, conflituoso. Segundo Vernant, "no plano intelectual como no domínio das instituições, só no fim alcançará todas as suas consequências: a polis conhecerá etapas múltiplas e formas variadas" (idem), pois desde os primórdios da constituição da pólis grega, momento em que a ordem sociopolítica se estruturava a partir do basileus, até a emergência da pólis democrática, houve um longo e tortuoso caminho.

O contexto arcaico remete a uma comunidade aristocrática cuja hierarquia era

tida por natural, de estruturas superpostas, em cuja cúspide dominavam um rei (basileús) e o conselho de nobres (áristoi), junto às assembléias gerais com um rol netamente subordinado. Dessa estruturação social e política se derivará o que o historiador W. G. Forrest (1988) chama de novo modelo grego: um magma comunitário em certa medida amorfo, desprovido de normas jurídicas claras e títulos legais definidos, respeitoso do caráter sagrado e imutável que transmitia a célula elementar da família e o lar (oikía); e, emanando do núcleo familiar em cujo seio seus membros se achavam unidos pelos laços sanguíneos dos antepassados e dos cultos ancestrais, uma distribuição representável por 
meio de estratos concêntricos e um desenho piramidal, no redor dos quais pululavam os camaradas e seguidores (bétairoi), servos e clientes, escravos e plebeus, aos que se somava, nos contornos inferiores, um terceiro e híbrido estrato de camponeses, artesãos e trabalhadores livres que não podiam, em virtude da origem, acreditar uma estirpe convertida em signo de prestígio e de predominância social (status). Entrava em funcionamento, atravessando essa complicada estratificação, um mecanismo cumulativo de agrupação: o génos ou clã, conjunto de famílias; as phratrías, reunião pela proximidade de vários géne irmãos; e a phylé ou tribo, comunhão de fratarias e via de ingresso à cidadania do porvir (Tierno, 2014, 6).

Com o passar do tempo, ocorreram uma sucessão de eventos que catalisaram mudanças político-institucionais na pólis, sendo importante citar, dentre todos os eventos, a revolução em Corinto que levou à derrubada do clã dos Baquiadas (ocorrida a partir de 650 a. C.), a constituição de Esparta onde Licurgo instaurou a lei constitucional (estimada entre 750 e 620 a. C.) e a codificação de Drácon e as reformas de Sólon ocorridas em Atenas (a partir de 594 a. C.). Embora as mudanças decorrentes destes eventos tenham se dado cada uma em seu ritmo e com suas particularidades, os três episódios tiveram como

denominador comum [a] substituição de uma elite aristocrática por outra, geralmente situada nas margens da nobreza, derivada de uma toma do poder que deveu contar, de modo significativo e provável, com o apoio militar procedente das classes médias hoplitas. Em compensação, cada mudança deu-se, como não podia ser de outra maneira, sob o signo de seu próprio ritmo e suas particularidades. Corinto não foi além da marca dos tiranos, potenciados pelos chamativos contatos com Egito; Esparta, por sua parte, viu-se freada pelo éthos fechado da sua comunidade, que conservou a base produtiva agrícola e os costumes atávicos (os usos das comidas em comum e da educação por tribos), ao passo que seu arranjo constitucional ia dirigido a sustentar uma cidadania militarizada e a assegurar um controle social dos homens e da propriedade igualitária assaz opressivo (ibid., 7-8).

Atenas, por outro lado, obteve maior sucesso na reforma de suas instituições ao aprofundar a participação popular. Vale apontar que Atenas "não constituía nem constituiria a única pólis democrática, embora possa ser considerada, em perspectiva, o exemplo que deixou mais e melhores documentos e literaturas” (ibid., 8). Apesar das vicissitudes, a pólis, “desde o seu advento, que se pode situar entre os séculos VIII e VII, marca um começo, uma verdadeira invenção: por ela, a vida social e as relações entre os homens temam 
uma forma nova, cuja originalidade será plenamente sentida pelos gregos” (Vernant, 2002, 53).

Para Vernant (ibid., 53-54) uma das maiores implicações da pólis democrática foi a preeminência da palavra sobre outros instrumentos do poder. Segundo Arendt, n'A condição bumana, nos gregos a liberdade só existiria na esfera política, pois a submissão e a imposição pela violência não teriam espaço na pólis. Ordem imposta, hierarquia, subordinação e violência eram elementos pré-políticos. Assim, a pólis, por ser a esfera onde o humano agia politicamente, era o campo do agir político (práxis) ${ }^{3}$, do discurso (lexis), onde o homem se destacava de um mero animal social. Arendt explica que o homem se coloca em duas esferas, oikos e pólis. A primeira, que se referia ao recinto privado, era constituída por uma gama de costumes e um código de honra atrelado aos heróis homéricos: a glória, os princípios da justiça-vingança e a absoluta determinação dos acontecimentos pelo basileus. Pressupunha um herói capaz de arrebatar a indeterminação. A esfera política, por outro lado, retrata a política ordenada. Se referia às ordenações das cidades-estado, onde os cidadãos são partes de um todo e, como partes, devem se submeter às leis e instituições.

Necessário frisar que polis e oikos não são esferas isoladas ou descontínuas. A segunda era a base econômica, biológica e social da primeira. $\mathrm{O}$ oikos produzia gerações de cidadãos pela reprodução, propiciando o bem-estar privado deles. Era, ainda, a esfera natural sobre a qual se funda a polis, agindo como mediadora entre a crueza da natureza e a pureza cultural. Também Vernant (2002, 48-50) aponta elementos de continuidade entre a pólis e o oikos: como uma ordem política não emerge 'do nada', deve-se ter claro que a pólis surgiu de uma sociedade estruturada no patriarcalismo do basileus (retratada nas épicas) e, de certa forma, as tragédias refletiram este momento de tensão entre a crise da tradição e a emergência do 'novo'.

O "novo" é, ao se colocar no horizonte humano, radicalmente contingente e indeterminado. Arendt expõe que o ser humano é o único ser que pode ser imortalizar, não porque é um animal social, mas porque age com liberdade e entre iguais em um campo construído no qual a ação de um ser humano

3. "A ação, única atividade que ocorre diretamente entre os homens, sem a mediação das coisas ou da matéria, corresponde à condição humana da pluralidade, ao fato de que os homens, e não o Homem, vivem na Terra e habitam o mundo. Embora todos os aspectos da condição humana tenham alguma relação com a política, essa pluralidade é especificamente $a$ condição - não apenas a conditio sine qua non, mas a conditio per quam - de toda a vida política" (Arendt, 2001, 8-9). 
pode ecoar na eternidade, como o ato de um deus. Neste sentido, o horizonte humano é a imortalidade e, na medida em que "imortais" não nascem todos os dias, aqueles que irão inscrever os seus nomes junto aos deuses serão os que, no campo de indeterminação, agirem de modo extraordinário, ou seja, romperem com a tradição, com o que está dado. Um dos principais pontos de tensão entre o oikos e a pólis é a questão da indeterminação e, por conseguinte, do novo. Se o oikos tem um telos claro - suprir as necessidades e determinações biológicas - bem como uma percepção nítida quanto aos meios para atingir o telos - produção, reprodução e hierarquia -, pode-se dizer que é um espaço dotado de uma ordem rígida, sem igualdade ou liberdade para que a administração seja eficiente em vista do telos. $\mathrm{Na}$ polis, por outro lado, nem o telos nem os meios para alcança-lo são determinados. Por mais que se diga que o objetivo da política é o bem comum, o político é marcado por um telos aberto e indeterminado, pois deve considerar o bem de e para todo o demos (pois todos são iguais e livres). Logo, a pólis, por ser o humano um ser político e indeterminado, é onde o homem se projeta como tal. O ser humano só é humano quando é político.

O contexto em que emerge o trágico é aquele onde uma lacuna se forma no coração social, ampla o suficiente para que a oposição entre pólis e oikos apareça e estreita o bastante para que não esgarce o corpo comunitário. A atmosfera da tragédia é o político. $\mathrm{O}$ ambiente de tensão, apreendido pelos trágicos, ao abrir um campo de potencialidades indeterminadas, reflete a ação humana de modo a despertar no público indulgência e temor, sendo, por isso, uma produção comunicativa que conecta, pelos atores, o dramaturgo e os expectadores assim como o discurso retórico conecta (pelo logos) orador e auditório (Tierno, 2009, 60). O temor despertado no público é o mesmo que arrebata os cidadãos quando um agente/ator político imprime um agir que abre o indeterminado, o "ainda não trilhado", o contingente. Este ator político, ao transgredir uma ordem, pode se imortalizar seja como herói trágico, seja como deus.

\section{O CONFLITO REFLETIDO NOS RELATOS TRÁGICOS}

O desafio de analisar a relação entre a tragédia e a pólis está no fato de que as peças não visavam a uma investigação sistemática (no sentido de logos) do político. Poderia se questionar, inclusive, se a problematização de questões políticas pelos trágicos foi consciente. Mas, mesmo que não fosse explícito 
ou mesmo intencional, as tragédias refletiram, criticaram e tencionaram o universo de valores. Hall (2010, 131-132), Vernant e Vidal-Naquet (1988) salientam que as peças trágicas, mais do que simplesmente retratar teatralmente ou artisticamente uma tensão entre uma tradição e a 'novidade', eram formas de criticar, confrontar e expor temas que, muitas vezes, não poderiam ser tratados em discursos políticos ou em certos espaços de institucionalidade. Ober e Strauss (1991, 243-244) chamam a atenção para a presença do conflito na polis ateniense e para o fato de que, como só a democracia se abre ao conflito, a tragédia reflete a emergência deste regime.

Para Vidal-Naquet e Vernant (1988, 40-44) a referida tensão entre tradição e a nova ordem se manifesta em diferentes níveis. Primeiro, na polaridade entre coro e herói trágico. O coro (coletivo anônimo que expressa os medos, esperanças, julgamentos e sentimentos dos expectadores da comunidade) não está preocupado em glorificar as virtudes heroicas, mas em expressar suas incertezas sobre ele. O herói trágico (indivíduo alheio à condição de cidadão comum) deixa de ser o exemplo cívico que era o herói homérico e se torna um problema para a pólis. No segundo nível, há um conflito entre os valores do herói e as instituições racionais. Ainda que as tragédias valorizem a virtude e a razão, questiona-se a possibilidade de se centrar toda a ordem política em um só agente, como se só ele se ligasse aos deuses e fosse virtuoso. Em terceiro, a tensão se manifesta entre o divino e o humano, entre suas respectivas noções de justiça e responsabilidade, entre uma tradição que crê nos deuses e profecias e outra que aposta na aptidão racional humana de agir e ser responsabilizado. Emerge a questão da responsabilidade e a díke oscila entre compreensão-responsabilidade-estabilidade e brutalidade-vingança-falta de sentido. Se, em certos momentos, a justiça é opaca, incompreensível, irracional, bruta, em outros, denota legitimidade, razão e equidade.

Neste sentido, a tragédia reflete o agonismo que marca o humano em todos os seus níveis. Se as peças abordam uma contradição em que o agente é forçado a fazer escolhas num palco político instável de valores ambíguos, evidenciando certa oscilação entre a 'ordem' racional e a contingência, Hall (2010, 4-5) coloca que o elemento chave para se compreender o relato trágico é o sofrimento. Segundo a autora, as tragédias são a representação de eventos que envolvem grande sofrimento, fazendo com que a audiência sinta pena daquele que sofre e, ao mesmo tempo, medo de que o mesmo ocorra com ela. Retomando, esquematicamente, a lição aristotélica, aquele que vive só é um deus ou um bruto. $\mathrm{Na}$ medida em que o ser humano vive com-os-outros (caso não o fizesse, não seria humano), sua existência é marcada por um 
conflito, um incessante agonismo entre o deus e a brutalidade que o habitam. Esta tensão que, embora seja a chave da humanidade, é causa do sofrimento humano.

Nietzsche (2007) expõe que a tragédia sintetiza dois impulsos fundamentais, o apolíneo e o dionisíaco. Apolo, deus que representa o lado luminoso da existência, gerador de formas puras e nobreza, é a divindade da temperança, da justa medida. Já Dionísio simboliza o fundo tenebroso, desmedido, destruidor das formas ordenadoras pela transgressão de limites. Sendo a maior encenação trágica realizada no festival religioso em tributo a Dionísio e sendo ela precedida por rituais que elevavam a polis, a tragédia seria capaz de conciliar a força cega e inexorável do destino que tudo destrói e aquilo que tenta resistir, o herói. Logo, a tragédia não é a negação da razão ou do ideal humano, mas um relato que evidencia a fenda entre o divino e a brutalidade. Hall $(2010,5)$ expõe que a tragédia explicita um sofrimento concentrado no tempo, no qual há sempre 'agonia'. Etimologicamente, agonia deriva de agónia, que, por sua vez, procede de agón, que remete a luta, combate, batalha. Este termo se refere, por exemplo, à batalha do moribundo contra a morte. Em algumas peças havia cenas que evidenciavam esta tênue fronteira entre o despertar do desejo (bruto) e o despertar de uma reação mais contemplativa (divina). Pois bem, já que é na pólis que o humano se projeta como tal (visando agir de modo a se imortalizar), e sendo o homem marcado por um existir agônico, as questões abordadas pelas tragédias não poderiam deixar de abordar o conflito humano na pólis.

Para que o homem se torne imortal, ele deve ter o potencial de se igualar aos deuses ou, ao menos, a prerrogativa de se colocar como o elemento central da realidade. Tal centralidade parece se manifestar no distanciamento dos deuses em relação ao imanente, ao campo de ação das personagens trágicas. Isso porque, diferentemente dos relatos homéricos, a presença física dos deuses e a direção divina direta da ordem humana sai de cena. Os deuses, mesmo que continuem sendo parte relevante das peças, passam a agir por meio de intermediário (oráculos, adivinhos, sacerdotes), deixando o papel de 'regentes' e se tornando influenciadores. Assim, o mundo ainda não foi confiado totalmente aos homens, mas os deuses já não têm o protagonismo que tiveram outrora. $\mathrm{O}$ agônico trágico é tamanho que ao mesmo tempo em que remete aos deuses homéricos, está circunscrito na ordem democrática, onde quem detém o protagonismo é o ator político, mas a contingência é pressuposta, já que o ser livre é indeterminado. 
Em Édipo rei, a própria resposta ao enigma da Esfinge demonstra a centralidade do humano, assim como a resposta de Creonte à pergunta de Édipo sobre o motivo pelo qual não se aclarou o 'triste evento' da morte de Laio (1.157-158) evidencia a questão da indeterminação. Creonte, ao ser indagado por Édipo sobre o motivo pelo qual os tebanos ainda não haviam resolvido o assassinato do rei anterior, ele responde que "A Esfinge, entoando trágicos enigmas não nos deixou pensar em fatos indistintos” (1.159-160). A simbologia de uma criatura metade humana metade animal não permitir que os tebanos pensassem sobre fatos incertos, indefinidos, é bastante forte. Sendo a indefinição uma marca da democracia, pode-se vislumbrar a importância de Édipo ao derrotar aquilo que impossibilitava a indeterminação. Ainda, o fato de a resposta ao enigma ser 'homem' é ainda mais sugestivo. Poderia se conjecturar se teria sido a partir desse momento que Tebas foi confiada aos homens, ficando os deuses relegados ao status de influências externas, possibilitando, com isso, o conflito entre a ordem humana (que só pode se colocar como tal pela saída parcial dos deuses) e a divina.

Édipo, por ser aquele que liberta os homens para pensar em "fatos indistintos", é quem instaura o novo, mas em um momento em que o "velho" ainda estava vivo e pulsante. Isso porque a fala através de enigmas, que era a característica central da Esfinge, não desaparece com ela. Tirésias, assim como os oráculos, continuavam a falar desta forma, já que o divino seria “enigmático" demais aos ouvidos mortais. Mais do que isso, sendo Édipo aquele que, além de libertar, governa de forma justa e sábia sem recorrer aos deuses, ele estaria reafirmando a ordem humana e a possibilidade de os homens ser completos. Por outro lado, por ter sido incapaz de resolver a peste sem que o futuro de Tebas fosse comprometido, tornando-se, ele mesmo, um indivíduo que fala por enigmas, seria possível perceber que Édipo é o indivíduo que cria uma relação incestuosa entre a ordem divina e a humana, entre a tradição aristocrática e a democrática, entre o enigmático mundo divino e a clareza da razão.

Também é válido notar que o reflexo da tensão da pólis democrática se fez notar no espaço onde os relatos eram retratados. Segundo Hall (2010, 129-132), é uma característica paradoxal da tragédia sobrevivente que, apesar de estar profundamente preocupada com o público e com a identidade do cidadão, seus relatos não se passavam nas arenas de discurso (Conselho, Assembleia ou tribunais), mas em um espaço limítrofe, fora do lar (oikos) mas não na pólis. "A atuação acontece no ponto preciso em que o véu foi destruído pela crise doméstica, revelando-os à visão pública e divulgando 
suas ramificações não só para a reputação pública das figuras centrais, mas também para a comunidade em geral”.

$\mathrm{E}$, ao retratar o momento em que embates familiares se projetavam para além do lar, a tragédia indica um contexto histórico em que os assuntos das grandes famílias eram uma questão pública. Ainda segundo Hall, a relação entre a família e a pólis não era uma simples antítese, já que a pólis era constituída por múltiplas famílias, e era o lugar onde o demos se reproduzia. A produção de novos cidadãos para perpetuar a democracia era algo de suma relevância. A própria crise de Tebas acarretada pela peste girava em torno da fecundidade e, por conseguinte, da perenidade dos cidadãos. Não obstante, a vida familiar de um cidadão era um aspecto político de sua identidade, pois era importante ser visto como um chefe responsável de uma casa bem ordenada. Além da peça Édipo rei, em outras histórias ocorre também uma desestabilização politizada do oikos como quando, por exemplo, Medeia mata os filhos (a continuidade) de Jasão, ao invés dele.

Mas, ainda, poderia se questionar: haveria, além deste, outro aspecto agônico na oscilação tensionada entre a pólis e o oikos? Uma resposta possível seria a de que os autores trágicos, de forma consciente ou não, estariam apontando aos seus expectadores os riscos de quando os conflitos privados facciosos ou familiares (sejam eles oriundos de traições, de lutas entre irmãos por poder, incestos, purgações de crimes) ganham espaço público, colocando o coletivo em risco. Se no momento em que as tragédias emergiram como um relato de grande relevância já havia um claro delineamento dos espaços da pólis, já havia, por conseguinte, clareza sobre a necessidade de abertura da ordem, bem como de pulverizar o poder para um demos mais amplo.

\section{O INQUÉRITO E AS DÍKE EM CONFLITO}

Édipo rei, por narrar uma investigação promovida por um indivíduo altamente virtuoso que se descobrirá como a causa dos males da pólis, deixa o referido conflito transparecer com certa clareza. Nesse sentido, é uma peça que viabiliza um campo de reflexão sobre as tensões: entre uma justiça divina e uma justiça humana; uma justiça homérica e uma justiça racional; um julgamento/julgador divino e um julgamento/julgador humano; o recurso aos deuses e o recurso às testemunhas. Mais ainda, por ser uma peça que relata uma investigação de um ator político pelo assassino de seu antecessor, visando promover a justiça, esta peça é um relato privilegiado acerca de uma 
tensão entre uma concepção de justiça arcaica, bruta e irracional, e uma concepção racional, institucional. Foucault ${ }^{4}$ apresenta relevantes reflexões sobre a tragédia de Édipo.

Se a tragédia reflete um contexto de conflito entre uma tradição em crise e a ordem que se consolidava, vale apontar alguns dos relatos desta tradição, sobretudo na questão da díke. Para Foucault, um primeiro modelo de justiça estaria presente na Ilíada e n'Os trabalhos e os dias. $\mathrm{Na}$ Ilíada, havia uma noção de justiça na passagem do relato da corrida de cavalos realizada nos jogos decorrentes da morte de Pátroclo. Os cinco competidores largariam numa ordem de acordo com a força, do mais forte (saindo em primeiro) ao mais fraco, de modo que Antíloco largaria em quarto e Menelau em segundo. Os corredores passariam por um obstáculo, onde havia uma testemunha, e retornariam ao ponto de partida. Todavia, devido à intervenção divina direta, Antíloco chegou primeiro e Menelau em segundo. Com isso, Menelau acusa Antíloco de cometer uma irregularidade.

O que é interessante notar é que Menelau, para provar a irregularidade de Antíloco, não recorre à testemunha, mas propõe que Antíloco jure diante de Zeus que não houve infração. Quando Antíloco hesita e se recusa a jurar, fica comprovada a irregularidade. Vale observar que Antíloco não cometeu de fato uma irregularidade, apenas se recusou a ceder lugar a Menelau no obstáculo onde só era possível a passagem de um. Além disso, a corrida não era bem uma competição, já que a ordem de chegada já estava definida na parti$\mathrm{da}$, sendo apenas um ritual para que a verdade predefinida da força dos competidores se desvelasse. Dessa forma, Antíloco, ao não deixar o mais forte passar, mesmo que não tenha cometido uma infração, fez com que a verdade não se manifestasse. E, ao recusar fazer o juramento, ele fez com que a uma verdade parcial (ofuscada em parte pela intervenção divina, já que o primeiro lugar não terminou a corrida) prevalecesse (Foucault, 2014, 41-43).

Em Os trabalhos e os dias, existiriam duas formas de dike: uma ruim, a justiça dos reis, dos chefes locais e aristocratas, sensíveis a presentes e a corrupções, que saqueavam os bens alheios; e a boa forma, que resolvia os

4. Foucault trata do tema do saber em Édipo em vários momentos. Segundo uma nota na edição publicada do referido curso, realizada sob a direção de Ewald, Fontana e Defert, "Foucault deu, ao menos, seis variações de sua leitura da tragédia de Sófocles" (Foucault, 2011, 223). A proposta de Foucault é analisar a tragédia como portadora de uma estrutura política de saber. Para ele, a correta análise da tragédia de Édipo seria a genealogia do estabelecimento da verdade segundo práticas judiciárias gregas (Foucault, 2002, 29-31). 
litígios com base em bons juramentos. Na má justiça cada demandante deveria jurar que dizia a verdade, apresentando, junto de si, partidários, que juravam com ele. O juramento dos partidários era um reforço social do litigante, já que eles se expunham à vingança divina junto com o litigante. Quanto maior o número de jurantes, maior a chance de êxito. Já na boa forma de dike, a resolução do litígio se baseava em três juramentos, um de cada litigante e o terceiro do juiz. O juramento do juiz o vinculava às consequências do julgamento, atando seu destino ao da sentença e expondo-se à vingança divina, o que não ocorria com os adversários (ibid., 56-57).

É necessário notar que nos modelos arcaicos a justiça era estabelecida sem o recurso a testemunhas, por um jogo de desafio, de promessa ou de recusa: “os adversários são literalmente 'postos à prova', numa espécie de jogo, de duelo ou de desafio, determinando-se a verdade pelo lado do vencedor do risco; qualquer instância como um júri ou um juiz não tem competência de decisão sobre a verdade" (Muchail, 2004, 75-76). Monod (1997, 59-60) explica que o testemunho se impõe na transição democrática. Assim, o modelo de díke descrito em Édipo rei, o inquérito (enquête), a verdade sobre o passado é determinada por quem viu e anunciou, isto é, baseada em testemunhos que, inclusive, têm o direito de opor-se aos governantes. Entretanto, o elemento testemunhal humano ainda não é suficiente, visto que ele vem se acoplar a uma profecia divina. Há, inclusive, a presença de um sujeito que oscila entre a ordem humana e a divina (Édipo) que, ao inquirir, pondera os saberes divinos e humanos. Isso porque se Édipo é aquele que, sozinho, resolve o enigma da Esfinge, também sozinho, governa Tebas de forma sábia e justa, em Édipo em Colono, a personagem se torna piedosa, fala em enigmas e transita entre a ordem humana e a divina.

Édipo rei começa quando Édipo, soberano e herói, tenta livrar Tebas da peste buscando fazer justiça ao assassinato de Laio. Para descobrir o autor do crime e acabar com a peste, ele utiliza o inquérito, procedimento denominado por Foucault como "lei das metades". O inquérito se caracteriza pela averiguação de indivíduos que revelam partes da verdade que ao final se encaixam, viabilizando que a justiça seja feita. Estas metades, por sua vez, se subdividem em duas grandes partes, uma referência à ordem divina e outra referente à humana. Isso porque, primeiro, é revelado pela instância divina que a peste se deve aos crimes de incesto e assassinato, bem como que Édipo teria praticado estes dois crimes. Em seguida, será revelado pelas lembranças de Jocasta, de Édipo e pelos testemunhos do mensageiro e do escravo que Édipo matou Laio e, sendo o filho perdido e Jocasta, desposara sua mãe. E, 
o mais intrigante, é sempre Édipo -o autor dos crimes; o herói salvador de Tebas e o criminoso causador da peste; o problema e a solução para a peste- a ponte entre a justiça divina brutal e incompreensível (que deve purgar uma maldição lançada sobre seu pai) e a humana.

Primeiramente, Édipo consulta Apolo, que revela a primeira metade: o país está atingido por conspurcação, que é a razão da peste, sem dizer quem conspurcou. Após, Creonte informa que a conspurcação se deve a um assassinato e, ao inquirir novamente Apolo, obtém mais uma meia verdade, que a vítima foi Laio. Então, Édipo interroga Tirésias, adivinho cego de Apolo, que, por se negar responder, é ameaçado, respondendo que foi o rei a autor dos crimes, completando-se a primeira parte do jogo de verdades, onde a verdade é revelada de forma futura e prescritiva, como uma profecia divina (Foucault, 2002, 34-35). Mas, para que a verificação seja plena, falta o testemunho do presente, para constatar que Laio era de fato pai de Édipo e que este o havia assassinado, o que será revelado também por meias verdades.

Quanto à ordem humana, a verdade também é dividida em duas: uma consagrada ao homicídio de Laio e a outra ao nascimento de Édipo, que preencherão a verdade divina. Sobre a morte de Laio, há uma revelação indireta de Jocasta, que afirma que Édipo não pode ser o assassino, pois Laio foi morto no entroncamento dos três caminhos, o que se ajusta à lembrança de Édipo, que diz ter matado um homem lá. Assim, estabelece-se a verdade quanto ao assassinato, com o ajustamento da profecia divina ao saber humano. Quanto ao nascimento de Édipo, o ajustamento ocorre pelo testemunho do mensageiro de Corinto e pelo testemunho do escravo. $\mathrm{O}$ primeiro revela que Édipo não é filho de Políbio, mas uma criança que lhe foi entregue, e o segundo atesta que ele entregou a criança que deveria abandonar ao mensageiro.

A verdade se constitui a partir de duas grandes metades, com a sobreposição de duas ordens: a divina-oracular e a humana-terrena. Os dois pares se adéquam no vácuo deixado pela profecia divina, transformando o enigma dos deuses em verdade completa. Essa transformação de saberes fragmentários numa verdade decorre do confronto e hierarquização de saberes gerados pelo inquérito, onde as meias verdades são confrontadas e se completam como fragmentos do símbolo universal, cuja totalidade reúne um critério de valoração de provas, saberes e das maneiras de atestá-los. Fica clara a tensão entre uma revelação divina e uma revelação humana que se completam e possibilitam a purgação dos crimes. 
Assim, se, nos termos de Monod $(1997,60)$, há um poder-verdade autocrático encarnado por Édipo, que afirma ser o único juiz do justo, bem como a emergência de um novo pensamento jurídico e político que reivindica o direito de opor a um poder sem verdade uma verdade sem poder, por outro lado, este relato mostra que a pretensa universalidade do conhecimento humano é precária e contingente (Alves, 2008, 117). A história de Édipo é um relato simbólico, uma história de fragmentos que circulam entre os personagens e, devido ao abalo da soberania régia, procura-se pela metade perdida. Se, por um lado, existem forças divinas que influenciam para que a justiça seja feita quanto aos atos de Laio, tal justiça é brutal e incompreensível aos olhos humanos (já que não há sentido em um filho pagar pelos atos de um pai), por outro, será Édipo a peça humana central que possibilitará esta justiça divina, bem como adequará esta díke divina à ordem humana. Ele investiga a causa da peste, causa esta ligada, em última instância, à maldição lançada sobre Laio. Ao estabelecer a verdade, atrelando um saber humano e testemunhal ao divino, Édipo se coloca como um lapso de transição entre a tradição e a nova ordem, que coloca o homem no centro da pólis. Édipo articula e reinscreve uma profecia e uma justiça divina em sua razão humana, o que subverterá a ordem soberana.

A enquête (protagonizada por Édipo) colocou a ordem humana numa situação de protagonismo em relação à divina, na medida em que esta não foi suficiente para apontar a causa da peste. O poder humano é tão importante que o próprio título da peça é Édipo rei. Em todo o decorrer da narrativa, o que está em questão é essencialmente o poder de um homem, conquistado, como ele mesmo diz, pela sua inteligência e sem a ajuda dos deuses. E, para se manter soberano, Édipo confronta o saber humano ao divino, indo da profecia até o testemunho presente. Enfim, Édipo, ao constituir-se um sujeito de saber capaz de estabelecer a verdade, colocou-se na posição em que ele, por critérios estabelecidos por ele mesmo, constitui a verdade no poder. Assim, será o inquérito de Édipo, e não a direção divina, que comanda a entrada de personagens, convocando-as, bem como será o comando do rei que levará à verdade. Os deuses, por mais que não tenham sua existência questionada, possuem um papel ora central (já que a profecia se realiza) ora pouco importante (já que é Édipo quem assume o controle de toda a situação de modo a resolvê-la).

Retomando as tensões mencionadas anteriormente - entre uma justiça divina e uma justiça humana; uma justiça homérica e uma justiça racional; um julgamento/julgador divino e um julgamento/julgador humano; o recurso 
aos deuses e o recurso às testemunhas - pode-se dizer que a díke humana ainda não está consolidada, visto que Édipo incorre numa profecia. Por outro lado, é graças a ele, um humano, que a justiça divina se concretiza. Nos termos de Vernant e Vidal-Naquet $(1999,57)$, “contrariamente à epopeia e à poesia lírica, onde jamais o homem é apresentado enquanto agente, a tragédia situa, logo de início, o indivíduo na encruzilhada da ação, face a uma decisão que o engaja por completo [...] uma justiça que luta contra outra justiça”.

O que é interessante notar é o agonismo que se instaura entre um julgador divino (Tirésias/Apolo) e o julgador humano (Édipo). O divino revela que Édipo é a causa da peste, o que remete a uma maldição lançada sobre Laio. E é Tirésias que diz que se Édipo pretende punir o autor dos crimes ele deve punir a si próprio. Não obstante, Édipo, sendo o julgador humano, irá sobrepor suas lembranças, as de Jocasta, assim como o testemunho de escravos sobre a palavra dos deuses. Se se pensar em Homero, fica claro que o julgamento divino (através do juramento, que ignora o testemunho) é o bastante, ao passo que no julgamento de Sócrates, com a pólis democrática já consolidada, a sentença humana foi o suficiente. Entretanto, uma vez que as tragédias representam a tensão entre estes momentos, foi necessária a participação divina e a humana, o juiz divino e o humano, uma profecia e um testemunho de um escravo.

É todo esse jogo complexo de conflitos, de reviravoltas, de ambiguidades que é preciso apreender através de uma série de distâncias ou de tensões trágicas: tensões no vocabulário, onde as mesmas palavras tomam um sentido oposto na boca dos protagonistas que as empregam, segundo as diversas acepções que a língua religiosa, jurídica, política, comum, comporta; tensão no seio da personagem trágica que aparece, ora projetada no longínquo passado mítico, herói de uma outra época, encarnando toda a desmedida dos antigos reis da lenda, ora vivo na época da cidade, como um burguês de Atenas, no meio de seus concidadãos; tensão no interior de cada tema dramático todo ato, como desdobrado, desenrolando-se em dois planos: de um lado, no nível da vida quotidiana dos homens; de outro, no nível das forças religiosas, que obscuramente agem no mundo. Para que haja consciência trágica, é preciso, com efeito, que os planos humano e divino sejam bastante distintos para se oporem (isto é, que se tenha destacado a noção de uma natureza humana), sem deixar, no entanto, de aparecer inseparáveis (Vidal-Naquet e Vernant, 1999, 57-58).

Além disso, ao mesmo tempo em que há a presença de um herói, alguém extremamente virtuoso, sábio e justo, sua virtude não é absoluta, mas colocada em perspectiva. Édipo não é mais o indivíduo que se destaca em abso- 
luto do ordinário (como o herói homérico), mas é constituído pela realidade. A pressuposição de que o ser humano é um ser-com-os-outros no mundo, o que decorre de se dizer que há um ethos ou um conjunto de ações que constituem édipo, é uma pressuposição de uma comunidade política. A este respeito Ahrensdorf $(2009,25-27)$ aponta que a virtude elevada de Édipo, ainda que seja um elemento da peça, é aparente. Isso porque o herói não tenta resolver a peste por ser radicalmente altruísta, mas para assegurar a sua soberania e a sua representação de virtude - elemento destacado também por Foucault. Além disso, por vezes, Édipo oscila entre a máxima virtude e o vício como quando, por exemplo, depois de descobrir que Jocasta era sua mãe, ele entra em sua casa pedindo uma espada para mata-la, o que não ocorre por ela já ter suicidado. Outro ponto destacado é o fato de Édipo, ao descobrir que Políbio havia morrido, não parecer triste pela morte de seu suposto pai, mas feliz por não ter sido ele o seu causador (antes de descobrir que ele não era filho biológico do rei de Corinto). Ainda, há passagens em que Édipo se mostra ambicioso ou prepotente em excesso, mostrando uma bybris não compatível com a virtude de um herói. Mas, ainda assim, ele teria sido um governante justo, sábio e virtuoso, bem como salvador de Tebas.

\section{ConsideraÇÕes Finais}

O estatuto de Édipo em seu aspecto contraditório é alguém que ao mesmo tempo está abaixo e acima do homem ordinário, é o herói mais poderoso, chegando a ser igual a um deus, e o mais "impuro" dos homens. "O homem, escreve ele [Aristóteles], é por natureza um animal político: aquele, então, que se encontra por natureza ápolis é ou phaûlos, um ser desprezível, um sub-homem, ou [...] acima da humanidade, mais poderoso que o homem”. A ambiguidade de Édipo está no fato de ele ser o humano que conduz o jogo da verdade divina, tendo como objetivo encontrar a causa da peste, com uma vontade obstinada associada ao alto conceito que ele tem de si mesmo, de sua capacidade, de seu julgamento e de seu desejo de conhecer a verdade a todo preço. E ainda que Tirésias, Jocasta e o pastor tentem pará-lo, eles fracassam, pois Édipo, por sua bybris, não se contenta com meias-medidas.

O equívoco nas palavras de Édipo corresponde ao estatuto ambíguo que lhe é conferido no drama e sobre o qual toda a tragédia está construída. Quando Édipo fala, acontece-lhe dizer outra coisa ou o contrário do que ele está 
dizendo. A ambiguidade de suas palavras não traduz a duplicidade de seu caráter, que é feito de uma só peça, mas, mais profundamente, a dualidade de seu ser. Édipo é duplo. Ele constitui por si mesmo um enigma, cujo sentido só adivinhará quando se descobrir, em tudo, o contrário do que ele acreditava e parecia ser. $\mathrm{O}$ discurso secreto que se institui sem que o saiba, no seio de seu próprio discurso, Édipo não escuta. E nenhuma testemunha do drama em cena, fora Tirésias, é capaz de percebê-lo. São os deuses que devolvem a Édipo, como eco de certas palavras suas, seu próprio discurso deformado ou invertido (Vidal-Naquet e Vernant, 1999, 76-77).

Para Vernant e Vidal-Naquet, Édipo está obstinado a encontrar o assassino pois tem Creonte como suspeito, já que o considera seu rival, alguém que teria inveja de seu poder e de sua popularidade. Assim, ao projetar sobre Creonte seu desejo excessivo por poder, Édipo se persuade de que seu cunhado, tomado pela inveja, procuraria tomar seu lugar. Esta seria a bybris do tirano que teria causado a sua própria queda.

A imagem mítica de um herói que, rejeitado, retorna como um vencedor, é algo que se prolonga no século $\mathrm{V}$, encontrando certa representação na figura do tyrannos. O tirano alcança a realiza pela via indireta e não pela descendência legítima, sendo aquele que se qualifica para o poder por seus atos, suas proezas. Assim, ele não reina por seu sangue, mas pelos seus atos e virtudes. O poder supremo que foi capaz de conquistar fora das normas comuns o colocou acima das leis e dos demais homens. O poder do tirano é comparável ao poder dos deuses, como um poder que define os mais fortes e os mais poderosos. O poder absoluto seria o poder de tudo fazer, de fazer o que se quer na hora que se quer, pois tudo lhe seria permitido. A outra face de Édipo, complementar e oposta a essa, seria o daquele indivíduo expulso de Tebas para afastar a polução. A peste que passa a assolar Tebas consiste em um esgotamento das fontes de fecundidade (a terra, os rebanhos, as mulheres não mais geram), e a peste passa a dizimar todos os vivos. Esterilidade, doença e morte seriam as manifestações de uma polução, de algo que desregrou o curso normal da vida (e neste caso, abalou ao oikos). Assim, trata-se de descobrir o criminoso e expulsá-lo, novamente, da cidade, ou, como coloca Hall $(2010,76)$ purgar a poluição.

Fora do jogo, excluído da cidade, afastado do humano pelo incesto e parricídio, Édipo se revela, no fim da tragédia, idêntico ao ser monstruoso que evocava o enigma cuja solução ele imaginava, no seu orgulho de "sábio" ter encontrado. Qual é, interrogava a Esfinge, o ser dotado de voz que tem dois, três e quatro pés? A pergunta apresentava confusas e misturadas as três idades que 
o homem percorre sucessivamente e não pode conhecer senão uma após a outra: criança, quando ele anda com quatro patas; adulto, quando ele se mantém firme sobre suas pernas; velho, apoiando-se na sua bengala. Identificando-se, ao mesmo tempo, com seus jovens filhos e com seu velho pai, Édipo, o homem de dois pés, apaga as fronteiras que devem manter o pai rigorosamente separado dos filhos e do avô, para que cada geração humana ocupe, na sequência do tempo e na ordem da cidade, o lugar que lhe convém. Última reviravolta trágica: é sua vitória sobre a Esfinge que faz de Édipo, não a resposta que ele soube adivinhar, mas a pergunta que lhe foi feita, não um homem como os outros, mas um ser de confusão e de caos, o único, dizem-nos, de todos aqueles que andam na terra, no mar e nas águas a "mudar sua natureza” em vez de conservá-la bem distinta. Formulado pela esfinge, o enigma do homem comporta, portanto, uma solução que, no entanto, se volta contra o vencedor do monstro, o decifrador de enigmas, para fazê-lo aparecer como um monstro, um homem em forma de enigma, e de enigma, desta vez sem resposta (VidalNaquet e Vernant, 1999, 98).

Transparece mais um ponto de tensão: uma desconfiança decorrente da desvinculação entre o exercício do poder e a virtude, desconfiança que não fazia parte da figura do basileus. Como já colocado, uma vez que a tragédia não representa a democracia, mas uma tensão a partir da qual a democracia emergirá, há marcas da democracia (indeterminação; preocupação com a justiça do nómos; presença da ordem humana; presença da retórica, de uma linguagem jurídica empregada nos tribunais). Há também a possibilidade do embate entre autoridade (rei; soberano) e não autoridade (testemunho de escravos e mulheres), o que só é possível fora do patriarcado, fora do oikos. Há, por outro lado, elementos de uma sociedade oligárquica (patriarcalismo; centralidade de um herói, mas que começa a ser questionada). Poderia se dizer que há na peça Édipo rei uma abertura, pois Édipo aceita a limitação de seu kratos e a imposição do nómos sobre ele. Entretanto, o que se sucede em Tebas não é uma abertura, o que é bastante sugestivo, pois, assim como Atenas, mesmo após a democracia, períodos de oligarquias e tiranias sobrevieram.

\section{REFERÊNCIAS BibLIOGRÁFICAS}

Ahrensdorf, P. (2009). Greek Tragedy and Political Philosophy: Rationalism and Religion in Sophocles' Theban Plays. Cambridge: University Press, 2009.

Alves, M. (2008). "Direito, poder e saber em Édipo Rei de Sófocles". Revista da Faculdade de Direito Milton Campos, 107-126. 
Arendt, H. (2001). A condição bumana. Trad. Roberto Raposo. Rio de Janeiro: Forense Universitária.

Bobbio, N.; Matteucci, N.; Pasquino, G. (1998). Dicionário de Política. Trad. Carmem C. Varriale. Brasília: Editora Universidade de Brasília.

Foucault, M. (2002). A Verdade e as Formas Jurídicas. Trad. R. C. M. Machado e E. J. Morais. $3^{a}$ ed. Rio de Janeiro: NAU Editora.

Foucault, M. (2011). Leçons sur la volonté de savoir. Édition établie sous la direction de F. Ewald et A. Fontana, par D. Defert. Paris: Seuil/Gallimard.

Foucault, M. (2014). Obrar mal, decir la verdad: la función de la confesión en la justicia. Curso de Louvaina, 1981. Trad. E. Castro. Buenos Aires: Siglo XXI.

GolDHiLl, S. (2008). "Greek drama and political theory”. In. Rowe, C.; Schofield, M. Greek and Roman Political Thought. Cambridge: Cambridge University Press.

Hall, E. (2010). Greek Tragedy: Suffering under the Sun. Nova Iorque: Oxford University Press.

Kury, M. (1990). Sófocles. Trilogia tebana: Édipo rei, Édipo em Colono, Antígona. Rio de Janeiro: Zahar.

Muchail, S. T. (2004). Foucault, simplesmente. São Paulo: Edições Loyola.

Monod, J. (1997). Foucault: La police des conduites. Paris: Éditions Muchalon.

Nietzsche, F. W. (2007). O nascimento da tragédia. Trad. J. Guinsburg. São Paulo: Cia das Letras.

Ober, J.; Strauss, B. (1991). "Drama, Political Rhetoric, and the Discourse of Athenian Democracy". In. Winkler, J. J.; Zeitlin, F. I. (orgs.). Nothing to Do with Dionysos? Athenian Drama in Its Social Context. Princeton: Princeton University Press.

Oliveira, R. (2013). Pólis e nómos: O problema da lei no pensamento grego. Belo Horizonte: Edições Loyola.

Strauss, L. (1998). What is Political Philosophy? And other Studies. Chicago: Universaty of Chicago Press.

Tierno, P. (2009). "Contingencia política e imitación trágica". Equipo Federal del Trabajo, 57-67.

Tierno, P. (2011). "La justicia y los antigos griegos. Anacronismo e irrupción”. Revista de teoría y filosofía política clásica y moderna, 11-43.

Tierno, P. (2014). "Formação da pólis e o surgimento da democracia na Grécia antiga: história e consciência da Atenas clássica”. Hologramática (Lomas de Zamora): 99-119.

Vernant, J. P. (2002). As origens do pensamento grego. Trad. Ísis Borges B. da Fonseca. Rio de Janeiro: Difel.

Vidal-Naquet, P.; Vernant, J. P. (1988). Myth and Tragedy in Ancient Greece. Trad. Janet Loyd. Nova Iorque: Zone Books.

Vidal-Naquet, P.; Vernant, J. P. (1999). Mito e tragédia na Grécia Antiga. São Paulo: Editora Perspectiva. 
